\title{
Effects of seasonality and feed quality on the feed requirements and live weight gain of young deer - a review
}

\author{
D.R. STEVENS, J.R. WEBSTER and I.D. CORSON \\ AgResearch Invermay, Private Bag 50034, Mosgiel, New Zealand. \\ david.stevens@agresearch.co.nz
}

\begin{abstract}
Red deer are a species that exhibit marked seasonal cycles in reproduction and growth in response to changes in day length. Changes in food intake throughout the year are primarily a function of the changing drive to grow within the animal in response to changing photoperiod, but may be modified by other factors including the energy content and type of diet, climate, and the physiological state and age of the animal. Feed quality also changes with season and red deer change their response to quality between seasons. This may be based on diet selection or on changes in digestive and metabolic processes.
\end{abstract}

Keyw ords: feed quality, red deer, seasonality

\section{Introduction}

This paper brings together evidence of seasonality of growth in the red deer (including the Elk sub species) and the influence of feed quality throughout the year. Variations in live weight gain between birth and 1 year of age have been measured in the New Zealand deer industry, and these include the effects of both seasonality and feed quality (Figure 1). Expected intake and performance of red deer, based on seasonal average requirements, has been calculated from previous work (Fennessy et al. 1981; Table 1). The final section of the paper will address the practical implications of these findings in designing diets to exploit these seasonal variations.

\section{Seasonality of intake and liveweight gain}

The seasonal patterns of food intake and live weight gain in red deer, in which values are lower during autumn and winter than in spring and summer, have been known for some time (Blaxter et al. 1974; Fennessy 1982; Suttie et al. 1983). Recent liveweight gain data (Figure 2) confirms this and gives an indication of some of the year to year variability that occurs in both the timing and extent of the changes.

Day length change, or photoperiod, has a principle influence on live weight gain and subsequently intake in red deer (Suttie et al. 1983), with the general pattern being low live weight gain and intake when day length is

Figure 1 Seasonal growth rates of young red deer from birth to slaughter (Barry et al. 1998; Beatson et al. 2000; J udson \& Nicol 1997; Stevens \& Corson, unpub. data; Webster et al. 2000).

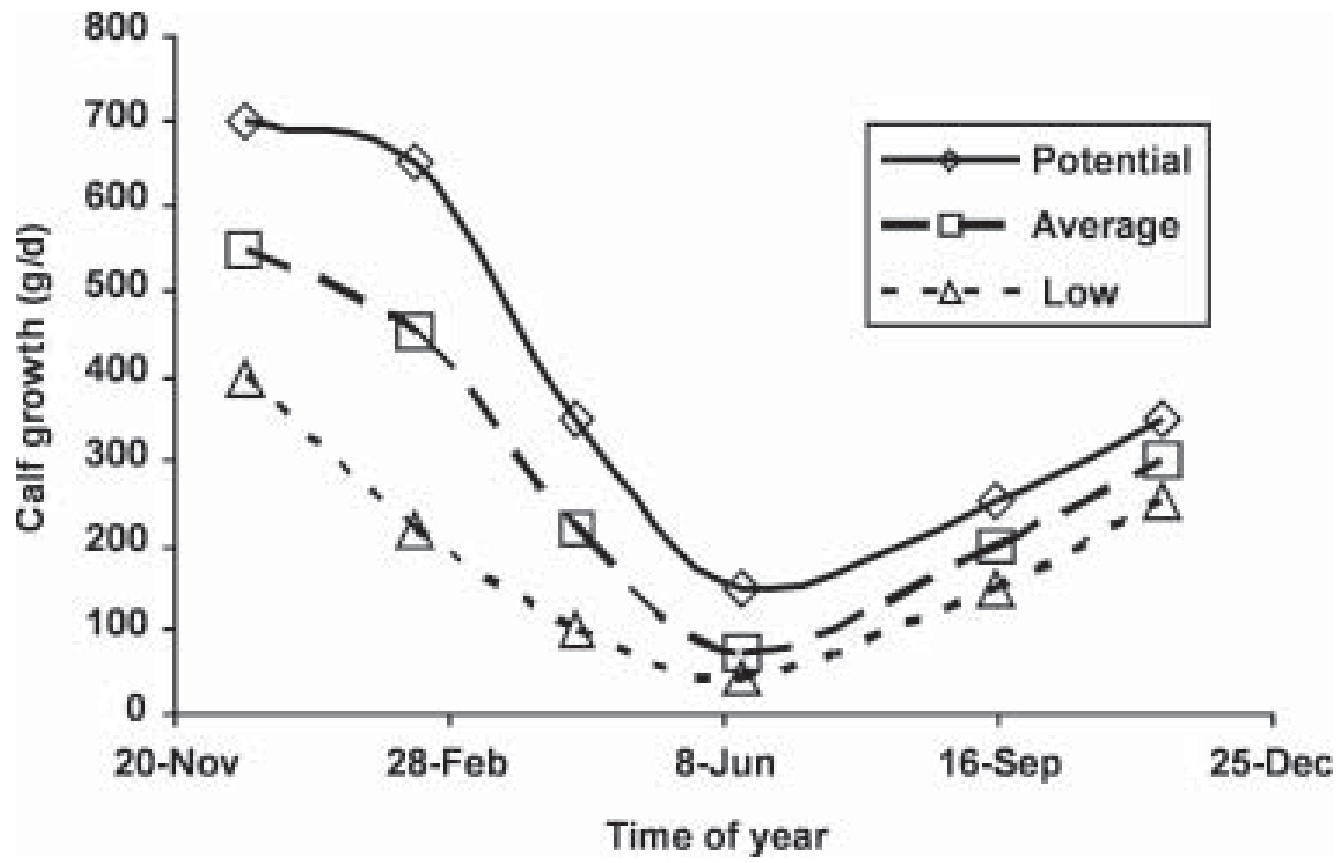


Table 1 Seasonal metabolisable energy requirements (MJ ME/d) for maintenance and live weight gain from weaning until slaughter for New Zealand red deer (adapted from Fennessy et al. 1981).

\begin{tabular}{|c|c|c|c|c|c|c|c|c|}
\hline \multicolumn{9}{|c|}{$\begin{array}{r}\text { Feeding requirements for maintenance and growth post-weaning } \\
\text { Liveweight }(\mathrm{kg})\end{array}$} \\
\hline & 40 & 50 & 60 & 70 & 80 & 90 & 100 & 110 \\
\hline Maintenance & \multicolumn{8}{|c|}{ Stag requirements (MJ ME/day) } \\
\hline Autumn (Winter Sheltered) & 11.9 & 14.1 & 16.2 & 18.2 & 20.1 & 21.9 & 23.7 & 25.5 \\
\hline Winter & 13.5 & 16.0 & 18.3 & 20.6 & 22.7 & 24.8 & 26.9 & 28.9 \\
\hline Winter (Indoors) & 8.0 & 9.4 & 10.8 & 12.1 & 13.4 & 14.6 & 15.8 & 17.0 \\
\hline Spring & 10.8 & 12.8 & 14.7 & 16.5 & 18.2 & 19.9 & 21.5 & 23.1 \\
\hline \multirow[t]{3}{*}{ Summer } & 9.9 & 11.7 & 13.4 & 15.0 & 16.6 & 18.1 & 19.6 & 21.1 \\
\hline & \multicolumn{8}{|c|}{ Gain $(g / d)$} \\
\hline & 50 & 100 & 150 & 200 & 250 & 300 & 350 & 400 \\
\hline Extra energy needed (MJ/d) & 2.7 & 5.3 & 8.0 & 10.6 & 13.3 & 15.9 & 18.6 & 21.2 \\
\hline
\end{tabular}

* Seasonal maintenance requirements are affected by the weather so may be lower when the temperatures are warmer than normal.

*Add extra energy for gain to the maintenance requirement to get total requirement.

Figure 2 The effect of seasonality on energy intake of young red deer adapted from Webster et al. (1998) and Webster et al. (2000), expressed as a) MJ ME per day and b) as MJ ME/kg BW ${ }^{0.75}$.

a) Intake expressed in MJ ME/day

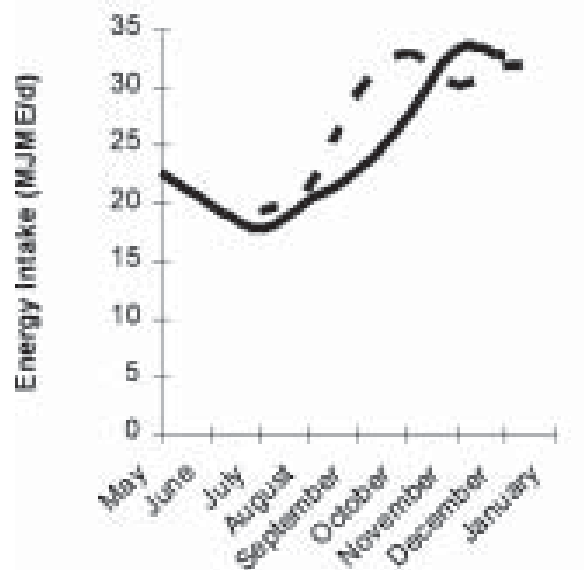

b) Intake expressed in metabolic body weight

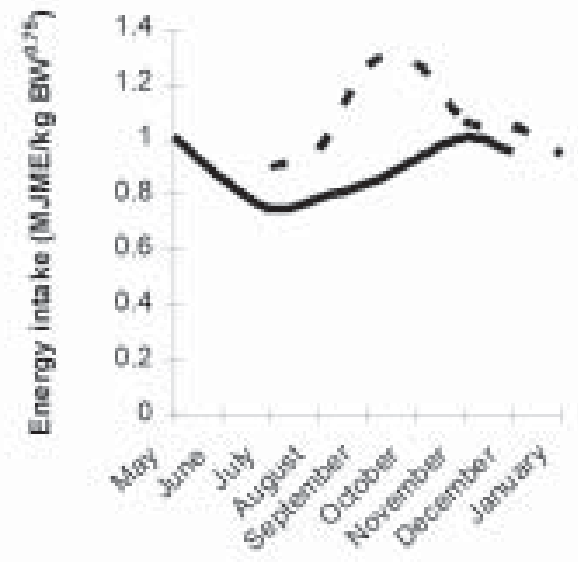

- - adapted from Webster et al. 1998

- adapted from Webster et al. 2000

short in winter, and high live weight gain and intake when day length is long in summer. Despite the increase in intake, increases in rumen size and retention time appear to maintain digestibility of the diet in spring (Domingue et al. 1991; Sibbald \& Milne 1993).

Additional factors which modify intake are imposed on the seasonal cycle. A major factor in adult animals is the reproductive cycle which produces a dramatic fall in food intake in stags during the rut (Fennessy et al. 1980).

Food intake is thought to be a consequence of meeting the demand for growth rather than the cause of the growth rate achieved (Kay 1988). A primary requirement for growth is energy and therefore intake may be adjusted depending on the energy content (We bster et al. 2000) and type of the diet (Webster et al. 2001) in order to meet energy demands. Other factors which increase energy demand such as pregnancy, lactation and cold (Adam et al. 1991) would therefore increase feed intake depending on quantity and quality of feed available.

\section{General responses to feed quality}

Feed quality has several impacts on the performance of ruminants. The data for red deer is relatively sparse and is included where possible in this section.

Feed quality, in this paper defined as metabolisable energy (ME), is the energy available which the animal 
can use for maintenance, gain or other productive purposes. It is ME which is the current standard when assessing feed quality in New Zealand. Evidence in deer suggests that there may be some changes in digestive efficiency, and hence ME, during the y ear. Galbr aith et al. (1998) found that relative urine and methane losses from elk declined between winter and spring, offsetting the lower dry matter digestibility that resulted from an increase in intake from 2.6 to $4.8 \mathrm{~kg} \mathrm{DM} / \mathrm{d}$.

Feed quality may also alter the efficiency of use of ME in the productive processes (AAC 1990). Research in sheep and cattle has shown that when ME is supplied by a low energy feed, the efficiency of use of that ME in the body is lower than if the feed was of a higher ME. AAC (1990) predict that a diet with an ME of $12 \mathrm{MJME} / \mathrm{kg}$ DM will be utilised with an efficiency of 0.74 while a diet with an ME of $8 \mathrm{MJME} / \mathrm{kg}$ DM will be utilised with an efficiency of 0.66 for maintenance in sheep and cattle. Therefore an animal consuming a low quality diet may need $10 \%$ more feed for maintenance than when it eats a high quality diet.

Effects on production may be even greater with the predicted energy requirement for gain decreasing from 42 to $62.5 \mathrm{MJME} / \mathrm{kg}$ live weight gain (AAC 1990) as the energy concentration of the diet declines from 12 to 8 $\mathrm{MJME} / \mathrm{kg}$.

Evidence in red deer from Webster et al. (2000) found no change in the efficiency of energy use for maintenance between diets from 8.5 to $11.0 \mathrm{MJME} / \mathrm{kg}$ in winter and spring, calculating a value of $0.45 \mathrm{MJME} / \mathrm{kg} \mathrm{BW} \mathrm{W}^{0.75}$. They did, however, measure a decline in the efficiency of energy use for live weight gain as the ME concentration of the diet declined during winter with a predicted efficiency for gain of $73 \mathrm{MJME} / \mathrm{kg}$ live weight gain at 8.5 MJME $/ \mathrm{kg}$ and $48 \mathrm{MJME} / \mathrm{kg}$ live weight gain at 11 $\mathrm{MJME} / \mathrm{kg}$. The efficiency of energy use in spring averaged 51.5 MJME/kg live weight gain.

Feed quality may also impact on the potential intake of the animal. The ME of a diet is directly related to the digestibility of the diet. Digestibility is the result of an interaction between the rate at which food is digested and the rate at which the undigested feed moves through the animals' digestive tract. Therefore a feed will be digested more completely if either it stays in the gut for a long time, or it breaks down more quickly. Low quality feed stays in the gut longer than high quality feed, but digests much more slowly.

The response of intake varies depending on the type of feed and the bulk limitations that are associated with the feed. This means that intake of feeds with low bulk limitations may increase as the feed quality declines. Webster et al. (2000) showed that weaners fed concentrate diets of varying energy concentration in winter and spring ate more of the low energy diet to ensure that energy intake met the energy requirements of the animal. The intake of forage based feeds such as pasture and silage are subject to much higher bulk limita tions (Forbes 1996). Webster et al. (2001) found that weaners fed silage did not increase feed intake to match potential energy demands during winter. They found that potential live weight gain and intake were only restored when significant amounts of concentrate were added to the diet. There is relatively little information available for red deer on pasture. Bulk limitations of forage may vary because the digestive physiology of the red deer allows an increase in rumen volume as intake increases from winter to spring, without any loss in digestibility (Domingue et al. 1991; Sibbald \& Milne 1993).

Results in the field are documented in the following sections and indicate the role of the interaction between the average quality of the diet offered and the selection of the animal to achieve a final outcome in live weight gain.

\section{Effects of diet quality at different times of the year}

The intake and performance of red deer on pasture may be modified both by seasonality and diet selection. Feral red deer choose a diet ranging from grass and legumes to browse shrubs and berries and nuts (Hofmann 1985). The diet of a red deer in the wild tends to vary with season based on the most nutritious and abundant feeds available at the time (Klein 1985). Under New Zealand grazing situations red deer prefer high quality species such as red clover, chicory, and white clover (Hunt \& Hay 1990). These factors lead to the selection of a diet of higher nutritive value than that on offer, to meet changing nutritional requirements.

\section{Autumn}

During autumn the live weight gain of weaned deer of approximately 3 to 4 months old grazing pastures ranging in herbage mass between 1800 and $3500 \mathrm{~kg} \mathrm{DM} / \mathrm{ha}$ was measured over several farms in the South Canterbury and North Otago regions (Figure 3). Increasing pasture quality during autumn led to an increase in live weight gain of approximately $24 \mathrm{~g} / \mathrm{d}$ per extra MJME/kg DM in the diet offered.AAC (1990) predictions for efficiency of energy use estimate an increase of $66 \mathrm{~g} / \mathrm{d}$ if intake remained the same. If the information from Webster $e t$ al. (2000) is used, where no change in energy use efficiency was recorded, then intake was increasing at 1.3MJME per MJME $/ \mathrm{kg}$ DM. This implies a very small increase in intake with changing energy density of the diet, and suggests either that the deer were selecting a diet of higher quality than that offered, or were increasing the digestibility of the feed. 
Figure 3 A relationship between live weight gain and the quality of feed offered to weaned calves in early and late autumn (from Beatson et al. 2000).

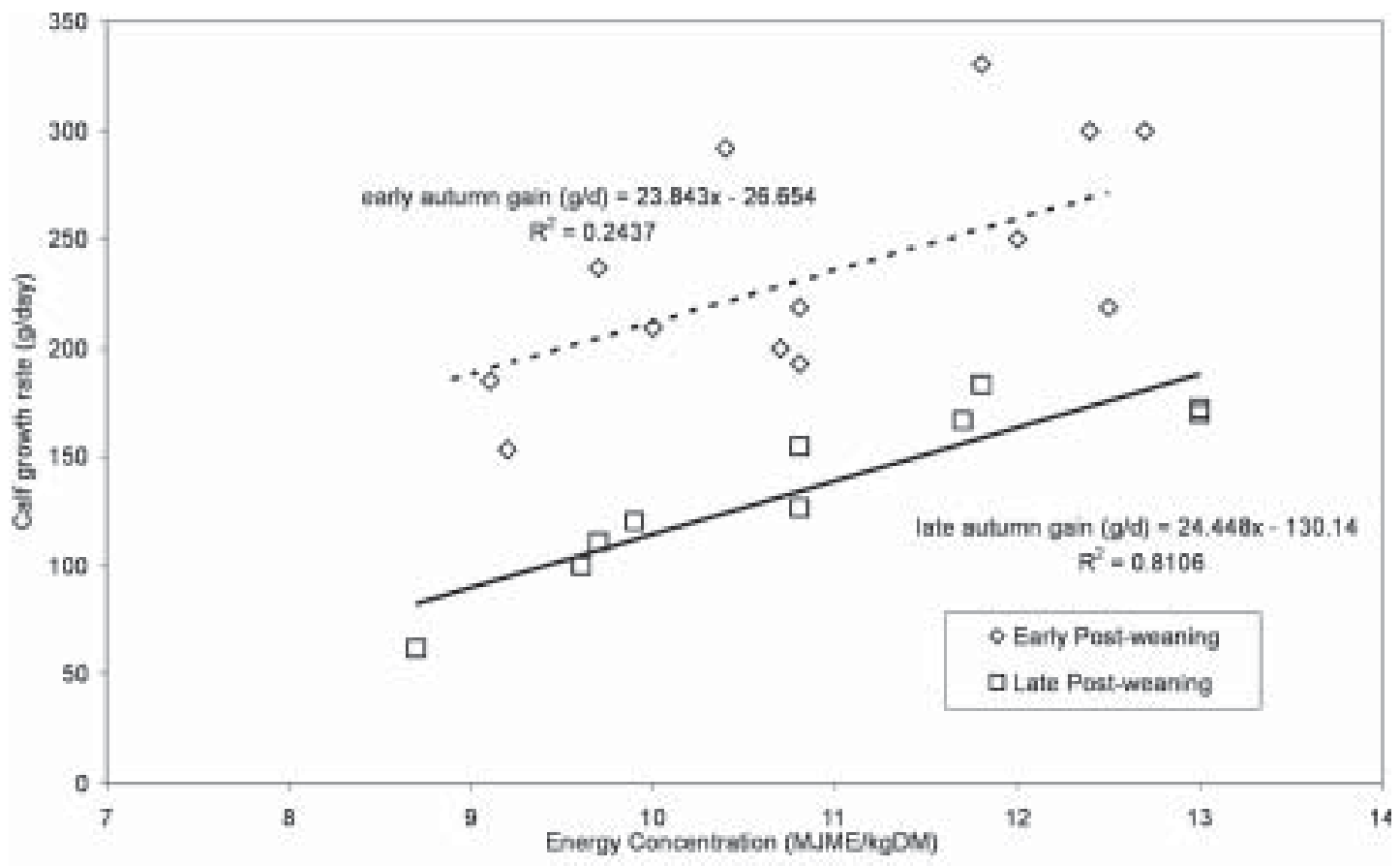

Winter

During winter the effect of reduced day length has the greatest effect on the intake of deer (Suttie et al. 1983). Research has shown it is energy intake that is limited during winter rather than total feed intake (Webster et al. 2000).

Liveweight gain data from field trials in South Canterbury (Table 2) provide a practical demonstration winter live weight gain of 160-180 g/d (Webster et al. 1997 ) in sheltered or indoor conditions was not reached. This suggests that either the climatic conditions were more severe in open pastures than on the outdoor feed pads used by Webster et al.(1997) or that the combination of feeds was not able to meet the ad libitum demand of the animal.

Often, weaner growth in winter is limited by the

Table 2 Effects of quality of pasture and feed on live-weight gain in winter on some New Zealand red deer farms (from Nicol \& Stevens 1999).

\begin{tabular}{|c|c|c|c|c|c|}
\hline \multirow[t]{2}{*}{ Farm } & \multicolumn{2}{|c|}{ Pasture Quality ${ }^{1}$} & \multicolumn{2}{|c|}{ Supplement offered } & \multirow{2}{*}{$\begin{array}{l}\text { Weaner gain } \\
\qquad(g / d)\end{array}$} \\
\hline & $\begin{array}{l}\text { Protein } \\
(\mathrm{g} / \mathrm{kgDM})\end{array}$ & $\begin{array}{c}\text { Energy } \\
\text { (MJ ME/kgDM) }\end{array}$ & Type & $\begin{array}{l}\text { Amount fed } \\
(\mathrm{kgDM} / \mathrm{hd} / \mathrm{d})\end{array}$ & \\
\hline 1 & 170 & 9.7 & Oats & 0.75 & 75 \\
\hline 2 & 170 & 9.9 & Baleage & 1 & 95 \\
\hline 3 & 178 & 12.0 & Peas & 0.75 & 70 \\
\hline 4 & 260 & 13.0 & Barley & 1.0 & 75 \\
\hline
\end{tabular}

${ }^{1} \mathrm{~A}$ mount of pasture offered unknown.

${ }^{2}$ All supplements offered contained 10 to $13 \mathrm{MJ} \mathrm{ME} / \mathrm{kgDM}$.

of this effect. Supplements of between 0.75 and $1.0 \mathrm{~kg} /$ head/d were added to a base diet of winter pasture. Supplements ranged from baleage to oats, barley and peas. These diets had an average energy content of between 10 and $13 \mathrm{MJME} / \mathrm{kg}$. The liveweight gain of 70-95 g/d regardless of supplement type indicates the limitation imposed by reduced day length in winter. The potential weather conditions rather than the feed type. Cold wet conditions have been estimated to increase the maintenance requirement of deer by up to $50 \%$ (Fennessy et al. 1981). Results from Webster et al. (1997) suggest that this may also be related to the level of feeding. Weaners eating a diet at near maintenance levels (approximately $1 \mathrm{~kg} \mathrm{DM} / \mathrm{d}$ ) ate proportionately 0.17 and 0.12 more outdoors than indoors in two winters respectively. The lower proportionate increase in the second year was associated with lower rainfall, higher solar radiation and lower average wind speed, while mean maximum and minimum temperatures were similar. Weaners fed ad libitum (eating approximately $1.6 \mathrm{~kg}$ 
$\mathrm{DM} / \mathrm{d}$ ) increased intake outdoors proportionately by 0.06 and 0.05 above weaners housed indoors. The extra heat of digestion and metabolism from the higher intake also resulted in a smaller absolute $(0.17$ and $0.1 \mathrm{~kg} \mathrm{DM} / \mathrm{d}$ in maintenance or ad libitum fed weaners respectively) increase in intake to meet the same energy demand.

When coupled with results from Webster et al. (2001) where only low intakes could be achieved on silage only diets, it would appear that high quality diets where $a d$ libitumintakes can be achieved will result in better growth in winter. This may be at a significant cost, and ther efore winter diets should be chosen with both growth and cost in mind.

\section{Spring}

Intake rapidly increases in early spring due to increasing day length. The timing of this increase in intake varies with latitude but commonly begins mid to late August. Intake rises for a period of 6 to 8 weeks. This period between mid August and late September often provides a window of opportunity to increase live weight gain with strategic feeding.

Reported spring live weight gains range from approximately 250 to $350 \mathrm{~g} / \mathrm{d}$ in red deer (Barry et al. 1998; Webster et al. 2000;
Webster et al. 2001). The difference of $100 \mathrm{~g} / \mathrm{d}$ is similar to winter and lower than that reported from late lactation and autumn. Pasture quality (ME) is often very high during spring (Hutton 1961), resulting in high potential growth rates at this time of year. Research at Invermay (Stevens \& Corson unpublished) showed that pasture quality during spring had an effect with weaner growth rates (Table 3) being greatest on pasture spelled for 6 weeks despite significant amounts of seed head being present. Further experimentation the following year also showed that live weight gain was related to changing feed quality (Figure 4). The initial interpretation of the

Table 3 Live weight gain of rising one year olds and pasture quality in spring (Stevens \& Corson, unpublished data).

\begin{tabular}{|c|c|c|c|c|}
\hline \multirow[b]{2}{*}{ Year $1^{1}$} & \multicolumn{3}{|c|}{ Regrowth period } & \multirow[b]{2}{*}{ LSD } \\
\hline & 3 week & 6 Week & 9 Week & \\
\hline Average live weight $(\mathrm{kg})$ & 85.1 & 86.8 & 82.1 & 7.1 \\
\hline Weight gain $(\mathrm{g} / \mathrm{d})$ & 265 & 311 & 144 & 98 \\
\hline Intake (kg DM/d) & 2.88 & 2.92 & 1.81 & 0.64 \\
\hline $\begin{array}{l}\text { Quality of the pasture offered } \\
\text { (MJ ME/kg DM) }\end{array}$ & 12.13 & 11.98 & 11.43 & 0.36 \\
\hline Year 2 & 3 week & 5 week & 7 week & \\
\hline Average live weight $(\mathrm{kg})$ & 93.0 & 92.7 & 93.6 & 5.1 \\
\hline Weight gain $(g / d)$ & 369 & 356 & 314 & 53 \\
\hline $\begin{array}{l}\text { Quality of the pasture offered } \\
\text { (MJ ME/kg DM) }\end{array}$ & 10.8 & 10.8 & 10.6 & 0.4 \\
\hline $\begin{array}{l}\text { Estimated quality of the diet } \\
\text { eaten }(\mathrm{MJ} \mathrm{ME} / \mathrm{kg} \mathrm{DM})^{2}\end{array}$ & 11.4 & 11.0 & 10.8 & 0.3 \\
\hline $\begin{array}{l}\text { Pasture allowance } \\
(\mathrm{kgDM} / \mathrm{head} / \mathrm{d})\end{array}$ & 9.3 & 8.1 & 7.7 & 1.4 \\
\hline
\end{tabular}

Figure 4 An effect of spring pasture quality on offer to ground level on rising one year old red deer live weight gain (Stevens \& Corson unpublished).

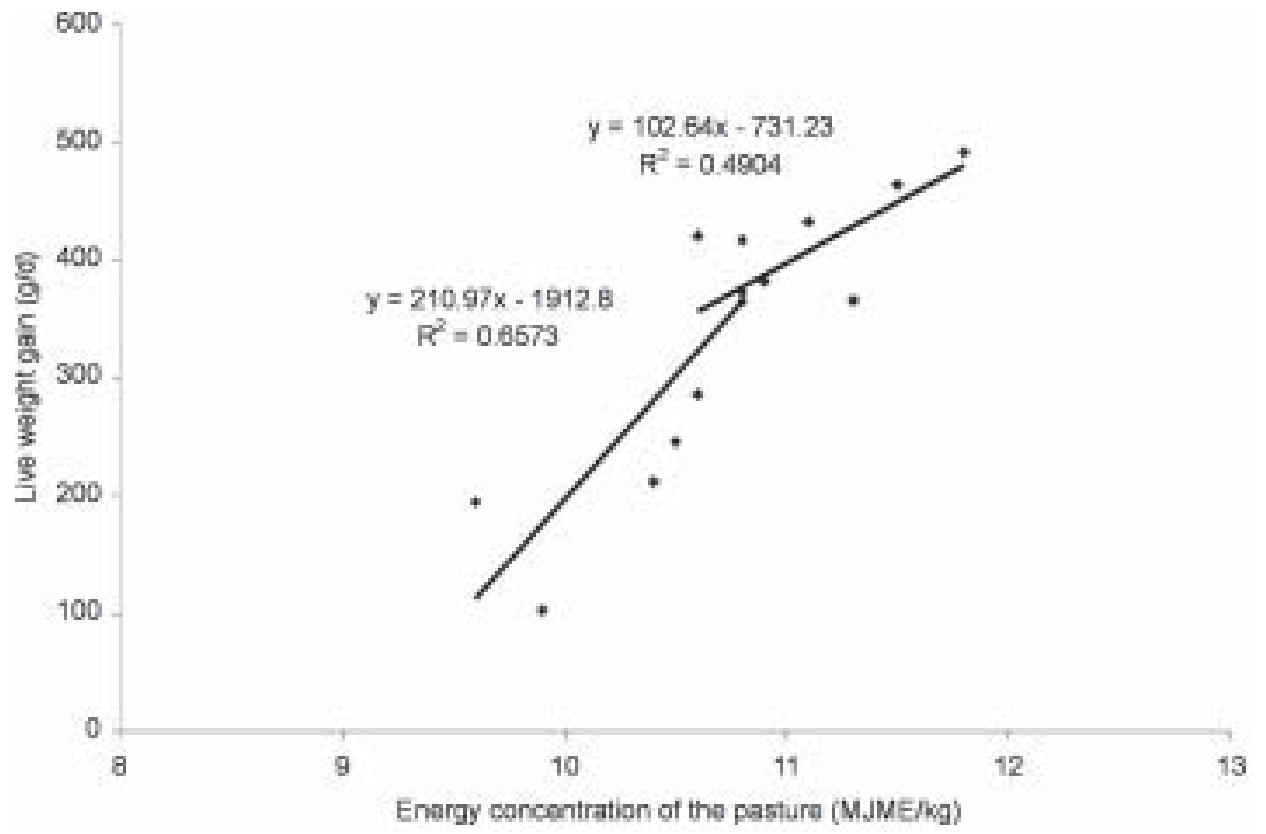


data assumed that the youngest pasture would have the highest ME. If fact, in many cases pasture spelled for 5 weeks had a higher ME than pasture spelled for three weeks.

\section{Matching diets to season}

The feed intake and live weight gain of red deer are sensitive to diet quality throughout the year, but the potential to influence diet quality and calf growth vary between seasons. Pasture quality has the greatest variability in summer (late lactation), then autumn and winter. The least sensitive season is spring as pasture quality is usually high.

The opportunity to increase calf live weight gain during late lactation from 220 to $600 \mathrm{~g} / \mathrm{d}$ (Figure 1) by improving $\mathrm{ME}$ of the diet on offer provides the greatest gain of any period. The use of strategic supplementation or specialist pastures and crops may help ensure that calf live weight gain is maximised when pasture quality cannot be maintained.

The feeding options chosen will depend on the reliability of rainfall, the extent of any feed deficit, and the ability to alter current management practises. Specialist pastures may be the best option where rainfall is reliable. Supplementing with grain at appropriate times offers good flexibility when droughts are occasional. The use of alternative feeds such as brassicas may have benefits when droughts are regular, providing the management systems can be altered to accommodate this. At this time attention must be given to providing high quality supplements, or a mix of supplements that achieve high intakes and performance. The use of supplements at this time may also help with calf acceptance of supplementation if it is required during the autumn or winter period after weaning.

The second period of high priority is during early autumn after pre-rut weaning. The best results are often when feeds used during lactation are continued to be fed to the ne wly weaned calves. Weaners are familiar with the feeds and the system of feeding. This reduces the problem of variable response or rejection of the diet offered.

Winter is of less importance because the animals' potential to grow is lowest then. During June and July silage only diets of $10.5 \mathrm{MJME} / \mathrm{kg}$ provided most of the needs of the weaner (Webster et al. 2001) but did not provide the opportunity for intake and live weight gain to incr ease in the late August and early September period (Webster et al. 2001). High quality silage fed in conjunction with a grain supplement towards the end of winter was more able to meet the increasing energy demand as live weight gains increased (Webster et al. 2001).

Are there any between season interactions such as compensatory gain? From experimentation to date it appears that there may be some small compensatory gain effects if weaners have been retained on diets very close to maintenance over the winter. Webster et al. (1997) show a small significant effect of approximately 40 to 50 $\mathrm{g} / \mathrm{d}$, but this was not enough to make up for the $140 \mathrm{~g} / \mathrm{d}$ advantage from feeding well over winter. Other experiments using varying ratios of silage to concentrates (Webster et al. 2000, 2001) or levels of winter pasture nutrition (Judson \& Nicol 1997) have found no evidence of compensatory gain in spring, when winter live weight gains were over approximately $50 \mathrm{~g} / \mathrm{d}$.

Finally the late winter/early spring period between mid August and late September often provides a window of opportunity to increase live weight gain. Often pasture supply and quality during late winter and early spring relies on pasture carried over from winter and may not be enough to meet this demand. Strategic feeding during this period can increase intake to match the increased potential for growth when many farm feeding systems have inadequate pasture available. Weaners fed high silage diets in late August and September continue to g row at the slower winter rates (Webster et al. 2001) so strategies should include adding extra grain supplements or using strategic feeds such as Italian ryegrass or brassicas to achieve the potential growth rate of weaners at this time.

\section{REFERENCES}

AAC 1990. Feeding standards for Australian Li vestock. Ruminants. CSIRO, East Melbourne. 266 pp.

Adam, C.L.; Haresign, W.; Cole, D .J.A. 1991. Nutrition and the implications of modifying the seasonality of farmed red deer. In: Recent advances in animal nutrition

Barry, T.N.; Wilson, P.R.; Kemp, P.D. 1998. Management of grazed pastures and forages for optimum deer production. pp. 141-157. In: Proceedings of the 2nd World Deer Farming Congress.

Beatson, N.S.; Campbell, A.G.; Judson, H.G. 2000. Deer Industry Manual, New Zealand. Deer Master, South Canterbury and North Otago Branch, NZDFA, Timaru.

Blaxter, K.L.; Kay, R.N.B.; Sharman, G.A.M.; Cunningham, J.M.M; Hamilton, W.J. 1974. Farming the Red Deer. The first report of an investig ation by the Rowett Research Institute and the Hill Farming Research Organisation, 93. Her Majesty's Stationery Office, Edinburgh.

Domingue, B.M.F.; Dellow, D.W.; Wilson, P.R.; Barry, T.N. 1991. Comparative digestion in deer, goats and sheep. New Zealand Journal of Agricultural Research 34: 45-53.

Fennessy, P.F. 1982. Growth and Nutrition.In: D. Yerex 
(Editor), The Farming of Deer. World Trends and Modern Techniques. Agricultural Promotion Associates Ltd., Wellington, New Zealand, pp. 105114.

Fennessy, P.F.; Greer, G.J.; Forss, D.A. 1980. Voluntary intake and digestion in red deer and sheep. Proceedings of the New Zealand Society of Animal Production 40: 158-162.

Fennessy, P.F.; Moore, G.H.; Corson, I.D. 1981. Energy requirements of red deer. Proceedings of the New Zealand Society of Animal Production 41: 167173.

Forbes, J.M. 1996. Integration of regulatory signals controlling forage intake in ruminants. Journal of Animal Science 74: 3029-3035.

Galbraith, J.K.; Mathison, G.W.; Hudson, R.J.; McAllister, T.A.; Cheng, K.J. 1998. Intake, digestibility, methane and heat production in bison, wapiti and white-tailed deer. Canadian Journal of Animal Science 78: 681-691.

Hofmann, R.R. 1985. Digestive physiology of the deer - their morphophysiological specialisation and adaptation. In: Biology of Deer Production pp. 393-407. Eds. Fennessy, P. F.; Drew, K. R., The Royal Society of New Zealand, Bulletin 22. Wellington.

Hunt, W.F.; Hay, R.J.M. 1990. A photographic technique for assessing the pasture species preferences of grazing animals. Proceedings of the New Zealand Grassland Association 51: 191-196.

Hutton, J.B. 1961. Studies of the nutritive value of New Zealand dairy pastures: I. Seasonal changes in some chemical components of pastures. New Zealand Journal of Agricultural Research 4: 583-590.

Judson, H.G.; Nicol, A.M. 1997. Effect of feeding level on the seasonal liveweight gain of young red deer (Cervus elaphus) and red/elk hybrid stags. Proceedings of the New Zealand Society of Animal Production 57: 139-143.
Kay, R.N.B. 1988. Seasonal variation of appetite in ruminants. pp. 34-45. In: D.J.A. Cole (Editor). Recent developments in ruminant nutrition 2. Butterworths, London,

Klein, D.R. 1985. Population ecology: The interaction of deer and their food supply. In: Biology of Deer Production pp. 13-22. Eds. Fennessy, P. F.; Drew, K. R., The Royal Society of New Zealand, Bulletin 22. Wellington.

Nicol, A.M.; Stevens, D.R. 1999. Trends in the use of forages in New Zealand deer production. Proceedings of the Fifth International Symposium on the Nutrition of Herbivores.

Sibbald, A.M.; Milne, J.A. 1993. Physical characteristics of the alimentary tract in relation to seasonal changes in voluntary food intake by the red deer (Cervus elaphus). Journal of Agricultural Science, Cambridge 120. 99-102.

Suttie, J.M.; Goodall, E.D.; Pennie, K.; Kay, R.N.B. 1983. Winter food restriction and summer compensation in red deer stags (Cervus elaphus). British Journal of Nutrition 50: 737-747.

Webster, J.R.; Corson, I.D.; Littlejohn, R.P. 2001. Effect of feeding supplements on the intake and liveweight gain of male red deer given silage during winter. Animal Science 73: 555-561.

Webster, J.R.; Corson, I.D.; Littlejohn, R.P.; Masters, B.M.; Suttie, J.M. 2000. Effect of diet energy density and season on voluntary dry-matter and energy intake in male red deer. Animal Science 70:547-554.

Webster, J.R.; Corson, I.D.; Littlejohn, R.P.; Stuart, S.K.; Suttie, J.M. 1998. Photoperiodic requirements for rapid growth in young male red deer. Animal Science 67: 363-370.

Webster, J.R.; Corson, I.D.; Littlejohn, R.P.; Suttie, J.M. 1997. Increased winter growth in male red deer calves under an extended photoperiod. Animal Science 65: 305-310. 